\title{
MENGATASI PROBLEMATIKA SAMPAH RUMAH TANGGA DI KOTA PONTIANAK
}

\author{
Donna Youlla, Ellyta, dan Sri Widarti \\ Program Studi Agribisnis, Fakultas Pertanian, Universitas Panca Bhakti
}

\begin{abstract}
ABSTRAK
Pertambahan jumlah penduduk yang pesat menyebabkan meningkatnya aktivitas sosial ekonomi masyarakat sehingga banyak menghasilkansampah. Rumah tangga adalah penyumbang sampah terbesar di Kota Pontianak. Kegiatan PKM ini bekerjasama dengan Badan Keswadayaan Masyarakat Sekip Darat Kota Pontianak. Tujuan dari kegiatan ini adalah untuk : 1)mengurangi masalah sampah baik organik dan anorganik, 2) memberikan tambahan pendapatan bagi kaum ibu dan remaja putri dari olahan sampah, 3) memotivasi kaum ibu dan remaja putri di lingkungan BKM Darat Sekip untuk mulai merintis keberadaan Bank Sampah Swadaya Masyarakat. Pelaksanaan kegiatan dilakukan demonstrasi dan pendampingan kepada anggota BKM. Kegiatan ini menunjukkan partisipan aktif dan antusias mengikuti kegiatan, yang ditunjukkan dengan banyaknya hasil kerajinan yang dihasilkan.
\end{abstract}

Kata kunci : Sampah Anorganik, Pemilahan Sampah, Bank Sampah

\section{PENDAHULUAN}

Sampah adalah bahaan-bahan atau materi yang terbuang atau dibuang dari segala aktifitas manusia dan alam yang belum memiliki nilai ekonomis. Dari waktu ke waktu seiring dengan bertambahnya populasi manusia dan aktifitas mereka membuat volume sampah bertambah dari hari ke hari sehingga menjadi masalah bagi bukan hanya pemerintah tetapi juga masyarakat itu sendiri.

Berdasarkan Undang-Undang No. 18 Tahun 2008, sampah adalah sisa kegiatan sehari-hari manusia dan/atau proses alam yang berbentuk padat. Pengelolaan sampah dimaksudkan adalah kegiatan yang sistematis, menyeluruh, dan berkesinambungan yang meliputi pengurangan dan penanganan sampah. Berdasarkan sifat fisik dan kimianya sampah dapat digolongkan menjadi: 1) sampah ada yang mudah membusuk terdiri atas sampah organik seperti sisa sayuran, sisa daging, daun dan lain-lain; 2) sampah yang tidak mudah membusuk seperti plastik, kertas, karet, logam, sisa bahan bangunan dan lain-lain; 3) sampah yang berupa debu/abu; dan 4) sampah yang berbahaya (B3) bagi kesehatan, seperti sampah berasal dari industri dan rumah sakit yang 
mengandung zat-zat kimia dan agen penyakit yang berbahaya.

Upaya pemilahan dan minimasi volume sampah dari mulai sampah ditimbulkan di lokasi timbulan sampah, khususnya di rumah tangga, akan mempermudah dan meningkatan efisiensi pada totalitas sistem persampahan, yang pada akhirnya akan mereduksi biaya penanganan sampah yang dibutuhkan. Pada sistem pemusnahan sampah, volume sampah yang telah tereduksi, disertai dengan sampah yang telah terpilah, akan sangat membantu para pemulung sampah untuk mengumpulkan sampah yang masih dapat didaur ulang.

Masyarakat di Kelurahan Darat Sekip (khususnya ibu-ibu rumah tangga) yang tergabung dalam Badan Keswadayaan Masyarakat BKM Sekip sebagian besar adalah sebagai ibu rumah tangga yang tidak memiliki kegiatan lainnya di luar kegiatan di rumah tangga mereka. Sebagian besar waktu mereka digunakan untuk mengurus kelurga atau ada juga yang sekedar membuka warung sembako didepan rumah. Ibu-ibu rumah tangga ini merupakan aktor penyumbang sampah terbesar, baik sampah organik maupun sampah anorganik. Sampah- sampah rumah tangga ini sebagian ada yang dibuang di pekarangan rumah atau di parit atau dibakar dan ada juga yang membuangnya di TPS terdekat.

Sampah-sampah ini dibuang tanpa dilakukan pemisahan sesuai jenisnya. Sampah anorganik yang dibuang dipekarangan rumah seperti kertas, plastik-plastik bekas kemasan, botol plastik, dan kaleng memerlukan waktu yang lama untuk dapat diurakan oleh organisme didalam tanah, menimbulkan kesan kumuh di lingkungan pemukiman warga, menjadi sarang nyamuk, lalat dan tikus yang dapat menularkan penyakit bagi manusia. Sehingga melalui kegiatan pelatihan pengolahan sampah anorganik menjadi berbagai aneka kerajinan tangan yang bernilai ekonomis seperti bunga, tempat tisue, tabungan, vas bunga dll, dapat dikiranya memberikan manfaat yang besar bagi ibu-ibu rumah tangga dan diharapkan dapat berpeluang untuk memperoleh tambahan pendapatan keluarga.

Dari permasalahan yang timbul menyangkut sampah rumah tangga dibutuhkan agen pelaksana yang dapat menerapkan minimasi dan pemilahan sampah semenjak ditimbulkannya sampah di rumah. Dalam hal ini, peran serta masyarakat akan sangat 
diharapkan untuk menjamin kesuksesan sistem tersebut. Anggota masyarakat yang tergabung dalam Badan Keswadayaan Masyarakatumumnya memiliki waktu lebih leluasa serta memiliki pengetahuan lebih dan lebih mudahnya mereka mengadopsi pengetahuan baru akan memudahkan dalam penerimaan mereka terhadap pengetahuan dan pengaplikasian hal baru.

\section{METODE PELAKSANAAN}

Kegiatan yang dilaksanakan berupa sosialisasi, penyuluhan, demonstrasi dan pelatihan serta bimbingan tentang pemilahan sampah yang meliputi :

1. Para peserta diberi informasi tentang teknologi pemilahan sampah untuk meminimasi timbulan sampah di TPA.

2. Demonstrasi diperagakan cara pemilahan sampah

3. Pemberian bimbingan dalam pembuatan aneka kerajinan berbahan plastik.

4. Evaluasi kegiatan dilakukan pada saat kegiatan berlangsung dan setelah kegiatan selesai. Selama kegiatan berlangsung diadakan diskusi tentang kegiatan pemilahan sampah serta pengolahan sampah rumah tangga tersebut. Evaluasi juga dilakukan beberapa minggu setelahnya untuk mengetahui apakah hasil pelatihan diterapkan atau tidak.

Partisipasi mitra dalam kegiatan ini yaitu sebagai peserta dan pelaku kegiatan dan juga menyediakan bahan berupa sampah anorganik berupa tabung, kaleng, atau wadah plastik dari rumah masing-masing untuk diolah pada pelaksanaan demonstrasi kegiatan.

\section{HASIL DAN PEMBAHASAN}

Sosialisasi dan Penyuluhan tentang Pengelolaan dan Pemilahan Sampah

Kegiatan ini dilaksanakan Kegiatan ini dihadiri oleh 20 peserta yang terdiri dari ibu-ibu rumah tangga dan remaja putri. Kegiatan ini bertujuan untuk memberikan pengetahuan dasar tentang pengelolaan dan pemilahan sampah di rumah tangga. Dalam hal ini akan dilakukan perubahan kebiasaan menjadi: sampah di pisahkan antara sampah organik dan anorganik, kemudian akan diolah secara mandiri menjadi kompos dan berbagai kerajinan yang bernilai ekonomis.

Berdasarkan diskusi dan tanya jawab dengan peserta terutama remaja 
putri diketahui bahwa pada umumnya peserta sudah mengetahui antara sampah organik (sampah basah) dengan sampah anorganik (sampah kering) seperti sampah kertas, botol, plastik dll. Para peserta PKM diminta untuk melakukan pemisahan antara sampah basah dan sampah kering di lingkungan rumah tangga masing-masing. Karena dari tingkat rumah tangga awal dari sampah dihasilkan dan diharapkan juga menjadi akhir dari sampah tersebut.

Sebagai suatu proses, pemusnahan sampah juga membutuhkan suatu syarat akan karakteristik input sampah. Misalnya, pemusnahan sampah dengan proses pengomposan, membutuhkan sampah dengan komposisi materi organik saja. Dalam hal ini, pemilahan yang dilakukan di TPA akan menurunkan kinerja proses yang dibutuhkan. Penurunan kinerja ini dapat dihitung sebagai besarnya biaya investasi tambahan yang dibutuhkan untuk lahan pemilahan sampah dan alat pemilah sampah yang datang ke TPA dengan volume sampah yang cukup besar.

Menurut Suarna (2008), faktorfaktor yang mempengaruhi pengelolaan sampah di antaranya: (1) sosial politik, yang menyangkut kepedulian dan komitment pemerintah dalam menentukan anggaran APBD untuk pengelolaan lingkungan (sampah), membuat keputusan publik dalam pengelolaan sampah serta upaya pendidikan, penyuluhan dan latihan keterampilan untuk meningkatkan kesadaran dan partisipasi masyarakat dalam pengelolaan sampah, (2) Aspek Sosial Demografi yang meliputi sosial ekonomi (kegiatan pariwisata, pasar dan pertokoan, dan kegiatan rumah tangga, (3) Sosial Budaya yang menyangkut keberadaan dan interaksi antarlembaga desa/adat, kegiatan ritual (upacara adat/keagamaan), nilai struktur ruang Tri Mandala, jiwa pengabdian sosial yang tulus, sikap mental dan perilaku warga yang apatis, (4) keberadan lahan untuk tempat penampungan sampah, (5) finansial (keuangan), (6) keberadaan Lembaga Swadaya Masyarakat (LSM), dan (7) kordinasi antarlembaga yang terkait dalam penanggulangan masalah lingkungan (sampah).

Ditinjau dari biaya pengoperasian-pemeliharaan-perawatan, dibutuhkan dana tambahan untuk membiayai petugas pemilah sampah, serta biaya pengoperasianpemeliharaan-perawatan alat pemilah sampah. Selain daripada itu, akan 
terdapat kesulitan operasional dalam pemilahan, karena besarnya volume sampah yang masuk ke TPA secara serentak, dan kesemuanya itu membutuhkan proses pemilahan. Berdasarkan hal tersebut, anggota BKM dapat memberikan gambaran kesulitan yang akan ditemui di TPA, jika pemilahan sampah dilakukan di sana.

Ditambahkan oleh Suarna (2008) pengelolaan sampah dimasa yang akan datang perlu memperhatikan berbagai hal seperti:

1. Penyusunan Peraturan daerah (Perda) tentang pemilahan sampah

2. Sosialisasi pembentukan kawasan bebas sampah, seperti misalnya tempat-tempat wisata, pasar, terminal, jalan-jalan protokol, kelurahan, dan lain sebagainya

3. Penetapan peringkat kebersihan bagi kawasan-kawasan umum

4. Memberikan tekanan kepada para produsen barang-barang dan konsumen untuk berpola produksi dan konsumsi yang lebih ramah lingkungan

5. Memberikan tekanan kepada produsen untuk bersedia menarik (membeli) kembali dari masyarakat atas kemasan produk yang dijualnya, seperti bungkusan plastik, botol, aluminium foil, dan lain lain.

6. Peningkatan peran masyarakat melalui pengelolaan sampah sekala kecil, bisa dimulai dari tingkat desa/kelurahan ataupun kecamatan, termasuk dalam hal penggunaan teknologi daur ulang, komposting, dan penggunaan incenerator.

7. Peningkatan efektivitas fungsi dari TPA

8. Mendorong transformasi (pergeseran) pola konsumsi masyarakat untuk lebih menyukai produk-produk yang berasal dari daur ulang.

9. Pengelolaan sampah dan limbah secara terpadu

10. Melakukan koordinasi dengan instansi terkait baik di pusat maupun daerah, LSM, Perguruan Tinggi untuk peningkatan kapasitas pengelolan limbah perkotaan

11. Melakukan evaluasi dan monitoring permasalahan persampahan dan pengelolaannya, kondisi TPA dari aspek lingkungan, pengembangan penerapan teknologi yang ramah lingkungan

12. Optimalisasi pendanaan dalam pengelolaan sampah perkotaan, 
pengembangan sistem pendanaan pengelolaan sampah

13. Konsistensi pelaksanaan peraturan perundangan tentang persampahan dan lingkungan hidup.

14. Meningkatkan usaha swakelola penanganan sampah terutama sampah yang mudah terurai ditingkat desa/kelurahan

15. Memberikan fasilitasi, dorongan, pendampingan/advokasi kepada masyarakat dalam upaya meningkatkan pengelolaan sampah.

Alangkah bijaknya jika pemilahan sampah dilakukan semenjak di rumah. Umumnya pemilahan dilakukan dengan memisahkan sampah organik (seperti sampah sisa dapur, sampah dedaunan, dan sampah kertas) serta sampah anorganik (seperti sampah plastik, sampah kaca, dan sampah kaleng). Dengan memilah berdasarkan 2 jenis tempat sampah yang berbeda, ada keinginan anak-anak untuk semakin tertarik dan belajar untuk menyadari, betapa sulitnya penanganan sampah jika kita sendiri tidak ikut peduli semenjak sampah ditimbulkan di rumah. Lebih jauh lagi, hal ini akan menjadi pembicaraan anak-anak di sekolah mereka masing-masing, mengenai budaya baru yang ditanamkan oleh sang ibu di rumah, untuk memilah sampah berdasarkan jenisnya.

\section{Memotivasi Pembentukan Bank} Sampah Swadaya Masyarakat.

Penting bagi rumah tangga untuk memiliki bak sampah sendiri di rumah mereka masing-masing. Hal ini dikarenakan untuk menghindari sampah berserakan di rumah sehingga akan menimbulkan bau dan pemandangan yang tidak sedap. Bak sampah dapat dipakai untuk membuang dan mengumpulkan sampah atau kotoran seperti daun, plastik, kertas. Pembakaran kotoran dari sampah untuk bak yang dibuat dari kayu diambil dahulu lalu dibakar di tempat. Sampah kompleks perumahan biasanya diambil dengan gerobak sampah/truk sampah dan dibuang ke tempat lain.

Dalam sistem pengelolaan sampah dengan menabung di bank sampah, diperlukan partisipasi masyarakat setempat.Melalui Bank Sampah. Partisipasi yang diberikan masyarakat berupa kewajiban melakukan pemilahan sampah rumah tangga berupa organik maupun anorganik yang dilaksanakan oleh masyarakat sendiri (Bachtiar, dkk, 2015). Dengan memberdayakan masyarakat di lingkungan sekitar maka 
sistem pengelolaan ini dapat berdiri secara mandiri tanpa bergantung kepada bantuan luar, serta kemandirian masyarakat dapat terwujud. Selain memberdayakan masyarakat, dalam upaya mewujudkan sistem pengelolaan sampah diperlukan juga upaya memberdayakan keluarga.

Tujuan dari Bank Sampah adalah untuk merubah perilaku masyarakat melalui pemahaman baru dalam pemanfaatan sampah. Masyarakat diajarkan bagaimanacara memilah sampah, untuk kemudian dikumpulkan dan disetor ke Bank Sampah yang nantinya akan dikonversi menjadi tabungan masyarakat. Dengan dukungan oleh struktur sumber daya yang baik dan bekerja untuk kepentingan sosial.Mekanisme dalam menabung sampah di bank sampah ada dua, yaitu menabung sampah secara individual dan menabung sampah secara komunal. Mekanisme menabung sampah secara individual, dimana warga memilah sampah kertas, plastik, kaleng/botol, dari rumah dan secara berkala ditabung ke bank sampah, sedangkan mekanisme menabung sampah secara komunal, warga memilah sampah kertas, plastik, kaleng/botol, dari rumah dan secara berkala ditabung di TPS (Tempat Penampungan Sementara) yang ada di tiap RT atau kelompok masyarakat (POKMAS), kemudian petugas bank sampah mengambil sampah di tiap TPS.

\section{Pengolahan Sampah Anorganik menjadi Aneka Kerajinan.}

Kegiatan ini dihadiri oleh 23 peserta yang terdiri dari ibu-ibu rumah tangga dan remaja putri. Agar kegiatan berjalan dengan lancar sampah anorganik yang digunakan adalah sampah dari sisa minuman dan obatobatan herbal yang sebelumnya sudah dicuci dan dibersihkan.Sebagai produk kreatif, karya kreasi sampah plastik memiliki nilai komersial yang menjanjikan. Produk ini memiliki daya jual yang dapat menghasilkan keuntungan (Putra dan Yurianda, 2010).

Kegiatan ini meliputi pengolahan sampah plastik menjadi produk kerajinan seperti tabungan, tempat tisu, vas bunga, tempat pensil dll. Sejalan dengan pendapat Nursruwening dkk (2015) bahwa berbagai macam sampah dari sampah domestik plastik dan kain perca setelah diolah kembali dapat menjadi produk kerajinan tangan (handicraft) yang bernilai ekonomis.

Kegiatan ini mendapatkan respon positif dari warga dilihat dari kehadiran 
peserta yang awalnya ditargetkan 15 peserta, ternyata warga yang hadir sampai 23 orang. Selain ini animo warga untuk membuat kerajian tangan sangat tinggi, dilihat dari banyaknya produk dari tabung plastik yang bisa mereka hasilkan.

Disamping itu adanya minat warga untuk membentuk bank sampah dilihat dari banyaknya pertanyaan mengenai cara membuat bank sampah dan hasil dan manfaat yang mereka peroleh dari pembentukan bank sampah tersebut.

Sosialisasi dan penyuluhan tentang pengelolaan dan pemilahan sampahdanpengolahan sampah anorganik menjadi aneka kerajinan merupakan salah satu bentuk pemberdayaan masyarakat dengan memanfaatkan sumber daya yang ada. Bahkan dengan memahami cara mengelola sampah dengan benar akan mengubah sampah yang dianggap sebagai sesuatu yang tidak berguna menjadi produk yang bernilai. Kegiatan ini sesuai dengan pendapat Fatoni dkk (2017) yang mengatakan melalui sosialisasi dan pelatihan yang seksama, kesadaran warga terhadap pengelolaan sampah menjadi maju dengan bisa membuat kerajinan yang bernilai ekonomi dari bahan sampah.

Kegiatan PKM ini mendapat apresiasi dari Ketua BKM Sekip Baru dikarenakan sosialisasi dan pelatihan pengolahan sampah organik maupun sampah anorganik dan inisiasi pembentukan bank sampah swadaya masyarakat belum pernah dilaksanakan di lingkungan BKM.

\section{KESIMPULAN}

Problematika sampah dapat diatasi dimulai dari lingkungan terkecil dengan berbagai cara antara lain:

1. Sosialisasi dan penyuluhan kepada warga tentang sampah dan pengelolaannya

2. Memotivasi masyarakat terutama ibu-ibu rumah tangga untuk mulai membuat Bank Sampah Swadaya di lingkungan sendiri.

3. Pelatihan pengolahan sampah anorganik menjadi aneka kerajinan yang bernilai ekonomis.

Pengelolaan sampah melalui kegiatan-kegiatan ini selain dapat menjaga kebersihan lingkungan juga dapat meningkatkan pendapatan masyarakat. 


\section{DAFTAR PUSTAKA}

Bachtiar, H., Hanafi, I., Rozikin, M.2015. Pengembangan Bank Sampah Sebagai Bentuk Partisipasi Masyarakat Dalam Pengelolaan Sampah (Studi Pada Koperasi Bank Sampah Malang). Jurnal Administrasi Publik (JAP), Vol. 3, No. 1.

Fatoni, N., Rinaldy Imanuddin L., Darmawan. A. R.Pendayagunaan Sampah Menjadi Produk Kerajinan. Dimas.Jurnal Pemikiran Agama untuk Pemberdayaan. Volume 17. No. 1 . UIN Walisongo. Semarang.

Hayat dan Zayadi. 2018, Model Inovasi Pengelolaan Sampah Rumah Tangga, Jurnal Ketahanan Pangan Vol. 2 No. 2 Desember 2018.

Hastuti, N, H, 2014,Bank Sampah, www.blogspot.com, diakses pada tanggal 10 Desember, 2019.

Muhammad, 2014, Profil Bank Sampah Indonesia. $\quad$ www.menlh.go.id, diakses pada tanggal 10 Desember 2019.

Nursruwening,Y, Widyandini, W, Wahyuningsih, E. S. 2015. Pembuatan Handicraft Menggunakan Bahan Olahan Sampah Domestik. Prosiding SENATEK 2015 Fakultas Teknik, Universitas Muhammadiyah Purwokerto. Purwokerto, 28 November 2015

Putra, P., H, Yuriandala, Y. 2010. Studi Pemanfaatan Sampah Plastik menjadi Produk dan Jasa Kreatif. Jurnal Sains dan Teknologi Lingkungan. Volume 2, Nomor 1, Januari 2010

Suarna, I.W. 2008. Model Penanggulangan Masalah Sampah Perkotaan dan Pedesaan. Jurnal Pusat Penelitian Lingkungan Hidup. Universitas Udayana. Bali. 